Fikroh : Jurnal Pemikiran dan Pendidikan Islam

Volume. 12, Number. 2, Juli 2019

p-ISSN : 2087-7501, e-ISSN : 2715-4459

HIm : 166-183

Journal Home Page : https://jurnal.stai-alazharmenganti.ac.id/index.php/fikroh

\title{
PERAN DAKWAH JAMAAH HADRAH HUBBUN NABI DALAM MENINGKATKAN SEMANGAT AKTIVITAS KEAGAMAN REMAJA DESA TANJUNGAN KECAMATAN DRIYOREJO KABUPATEN GRESIK
}

\author{
Suparno \\ STAI Al-Azhar Menganti, Gresik, Indonesia \\ suparnoalazhar@gmail.com
}

\begin{abstract}
Islam is a religion of da'wah, meaning religion that always encourages its adherents to always active Islamic teachings. Even the advanced pullback of Muslims relies heavily on the da'wah activities it does. Da'wah can be done by means of Bill-oral, Bil Qalam, bil of things and can go through various forums as long as its purpose is to invite to live the command of Allah SWT in the form of faith and exempvises his apostles. Through Da'wah which is filled with Dhikerullah, praise the Prophet Mubammad with the accompaniment of the music that will captivate the society especially the youth follow the religious activities carried out by the congregation Sulthan. From the background, there will be a desire from researchers to know the extent of the role of the propagation of the Congregation of the Hubbun Prophet in increasing the spirit of the activity of youth religious activities village of Driyorejo District of Gresik Regency. And what are the encouraging factors in increasing the spirit of the youth's religious activities. This research uses qualitative descriptive research. Data collection using observations, interviews, and documentation. Through interviews and observations it is known that the main subjects studied were the youth members of the Hubbun prophet. The results showed that the mosque returned to life with all the religious activities and the taxon of youth by the worshippers of the Prophet Hubbun. This activity is done by preaching the congregation is a dhikr, shalawat with the suffix Sulthan rebana, Tablil, Ad-Diba'i, Yellow Book and others. With the dhiker and Shalawat the youth will feel calm in their souls so that they can think clearly and do good things. And through the Mauidzah Hasanah and good guidance can affect the morality and the lives of the youth who follow the congregation of the Sulthan. The spirit, cooperation, feeling of sincerity and high sacrifice from the managers in spending time for the activities of the congregation and the community who are conducive to make the activities of the Congregation of the Prophet Hubbun can run well.
\end{abstract}


Keywords: da'wah, Hadrah, religious activity.

\begin{abstract}
Abstrak
Islam adalah agama dakwah, artinya agama yang selalu mendorong pemeluknya untuk senantiasa aktif meyiarkan ajaran Islam. Bahkan maju mundurnya umat Islam sangat bergantung pada kegiatan dakwah yang dilakukannya. Dakwah bisa dilakukan dengan cara bil-lisan, bil qalam, bil hal dan bisa melalui berbagai forum asalkan tujuannya sama yaitu mengajak untuk menjalankan perintah Allah SW'T yang berupa iman serta meneladani para rasul-Nya. Melalui dakwah yang diisi dengan dzikrullah, memuji Rasulullah SAW dengan diiringi musik hadrah maka akan memikat masyarakat khususnya remaja mengikuti aktivitas keagamaan yang dilaksanakan jamaah hadrah. Dari latar belakang tersebut maka timbul keinginan dari peneliti untuk mengetahui sejauh mana peran dakwah jamaah hadrah Hubbun Nabi dalam meningkatkan semangat aktivitas keagamaan remaja Desa Tanjungan Kecamatan Driyorejo Kabupaten Gresik. Dan apakah faktor yang mendorong dalam meningkatkan semangat aktivitas keagamaan remaja tersebut. Penelitian ini menggunakan penelitian kualitatif deskriptif. Pengumpulan data menggunakan observasi, wawancara, dan dokumentasi. Melalui wawancara dan observasi diketahui bahwa subyek utama yang diteliti adalah para remaja yang menjadi anggota jamaah hadrah Hubbun Nabi. Hasil penelitian menunjukkan bahwa masjid kembali hidup dengan segala aktivitasaktivitas keagamaan dan taklim untuk remaja oleh jamaah hadrah Hubbun Nabi. Aktivitas yang dilaksanakan dakwah jamaah ini adalah dzikir, Shalawat dengan diiringi tabuhan hadrah rebana, tahlil, Ad-Diba'i, pengajian kitab kuning dan lain-lain. Dengan dzikir dan shalawat tersebut para remaja akan merasakan ketenangan dalam jiwa mereka sehingga mereka mampu berfikir dengan jernih dan melakukan hal yang baik. Dan melalui mauidzah hasanah serta bimbingan-bimbingan yang baik dapat berpengaruh terhadap akhlak dan kehidupan para remaja yang mengikuti jamaah hadrah tersebut. Semangat, kerja sama, rasa ikhlas dan rela berkorban yang tinggi dari para pengurus dalam meluangkan waktunya untuk aktivitas jamaah serta masyarakat yang kondusif membuat aktivitas jamaah hadrah Hubbun Nabi dapat berjalan dengan baik.
\end{abstract}

Kata kunci: dakwah, hadrah, aktivitas keagamaan.

\title{
A. Pendahuluan
}

Islam adalah agama dakwah, Islam disebarluaskan dan diperkenalkan kepada umat manusia melalui aktivitas dakwah, tidak melalui kekerasan, pemaksaan dan kekuatan senjata. Islam tidak membenarkan pemeluk-pemeluknya melakukan pemakian terhadap umat manusia, agar mereka mau memeluk agama Islam. ${ }^{1}$ Obyek dakwah dalam penelitian ini

${ }^{1}$ Masyhur Amin, Dakwah Islam dan Pesan Moral (Jakarta: Al Amin Press, 1997), 1. 
adalah para remaja di Desa Tanjungan. Karena remaja merupakan generasi penerus bangsa yang perlu bimbingan dalam menghadapi tantangan di era global seperti saat ini. Penelitian ini dilakukan di Desa Tanjungan karena penulis merupakan penduduk asli dan berdasarkan hasil wawancara dengan Imam Samsul Huda (salah satu pemuda di Desa Tanjungan): "Banyak remaja di Desa Tanjungan yang kurang memiliki akhlak yang baik, hal ini bisa dilihat dari perilaku remaja sehari-hari seperti kurangnya sopan santun dan tata krama remaja terhadap orang yang lebih tua dan juga sudah terbiasa mengucapkan kata-kata kotor. Banyak yang terjerumus pada hal-hal negatif diantaranya adalah pergaulan bebas, minuman keras, terlibat dalam perkelahian dan tindak kriminal lainnya." ${ }^{2}$

Beberapa faktor yang mempengaruhi remaja melakukan hal negatif tersebut adalah yang pertama karena faktor lingkungan, kurangnya asupan tentang ajaran, nilai-nilai dan pengetahuan agama menjadikan mereka tidak bisa menahan diri dari hal-hal yang buruk dan menjadi larangan agama. Kedua adalah karena terlalu banyak waktu luang yang tidak digunakan untuk beraktivitas sehingga memicu remaja pada hal-hal yang negatif tersebut. Aktivitas keagamaan remaja yang ada di Desa Tanjungan Kecamatan Driyorejo Kabupaten Gresik sekarang ini adalah Jamaah hadrah yang dibentuk oleh Organisasi Remaja Masjid Bahrul Ulum NU yang diberi nama Hubbun Nabi. Jamaah ini seolah-olah menjadi jantung dari aktivitas keagamaan remaja di Desa Tanjungan. Melalui jamaah ini semangat para remaja untuk melaksanakan aktivitas keagamaan meningkat. Aktivitas ini sangat membantu remaja mengisi waktu luang mereka sehingga bisa meminimalisir remaja mengisi waktu luangnya dengan melakukan hal-hal yang negatif yang menjadi larangan agama.

\section{B. Metode Penelitian}

Berdasarkan latar belakang di atas, maka fokus masalah dalam penelitian ini adalah: Bagaimana aktivitas keagamaan remaja di Desa tanjungan Kecamatan Driyorejo Kabupaten Gresik? Bagaimana peran dakwah jamaah hadrah Hubbun Nabi dalam meningkatkan semangat aktivitas keagamaan remaja Desa Tanjungan Kecamatan Driyorejo Kabupaten Gresik? Apa faktor pendukung dan penghambat jamaah hadrah Hubbun Nabi dalam

\footnotetext{
2Imam Samsul Huda, Wawancara, Driyorejo, 10 Juli 2018.
} 
meningkatkan semangat aktivitas keagamaan remaja Desa Tanjungan Kecamatan Driyorejo Kabupaten Gresik?

\section{Hasil dan Pembahasan}

\section{Remaja dan Problem Keagamaannya}

Istilah asing yang sering dipakai untuk menunjukkan arti remaja antara lain: Puberteit, Adolescentia, dan youth. Dalam bahasa Indonesia sering pula dikatakan pubertas atau remaja. Dalam berbagai macam kepustakaan istilah-istilah tersebut tidak selalu sama uraiannya. Puberty (Inggris) atau Puberteit (Belanda) berasal dari bahasa Latin: Pubertas, yang berarti kelaki-lakian, kedewasaan yang dilandasi oleh sifat dan tanda tanda kelaki-lakian. Adolescentia berasal dari bahasa Latin Adulescentia. Maksudnya adalah masa muda, yakni antara umur 17 dan 30 tahun. $^{3}$

Akhir-akhir ini melalui berbagai atat komunikasi masa, baik melalui bacaan atau sandiwara-sandiwara di layar televisi, remaja banyak dijadikan obyek pembahasan. Para ahli pendidikan menganggap bahwa melihat kejahatan pada layar bioskop dapat merangsang remaja untuk turut mencoba melakukan kejahatan dan kenakalan. Haris memandang sikap remaja terhadap agama pada umumnya dapatlah dibagi menjadi empat bagian yaitu: ${ }^{4}$ (1) Percaya ikut-ikutan, (2) Percaya dengan kesadaran, (3) Percaya dengan keraguan (kebimbangan), (4) Tidak percaya sama sekali

\section{Peran Dakwah Dalam Kehidupan}

Dakwah berasal dari bahasa Arab, da'a-yad'u-du'a an/da'watan yang artinya memanggil, mengundang. ${ }^{5}$ Arti dakwah menurut bahasa (etimologis) adalah: Panggilan, seruan, ajakan. Dakwah dapat diklasifikasikan menjadi dua bagian besar, yaitu dakwah fardiyah dan dakwah jama'iyyah. ${ }^{6}$

a. Dakwah Fardiyah

Dakwah fardiyah adalah merupakan upaya dakwah yang dilaksanakan oleh seorang da'i yang memiliki keahlian dan pengalaman, kepada seorang mad'u yang dipilihnya sekian banyak orang.

\footnotetext{
${ }^{3}$ Singgih Dirga Gunarsa, Psikologi Remaja (Jakarta: BPK Gunung Mulia, 1978), 14-16. ${ }^{4}$ Singgih Dirga Gunarsa, Psikologi Remaja.

${ }^{5}$ Ahmad Warson Munawwir, Al-Munawnir, Kamus Arab-Indonesia (Surabaya: Pustaka Progressif, 1997), 438. ${ }^{6}$ Masyhur Amin, Dakwah Islam dan Pesan Moral, 3-7.
} 
b. Dakwah Jama’iyyah

Pelaksanaan dakwah jam'iyyah adalah tugas wajib yang berat, yang harus dikerjakan oleh kaum muslimin (secara berjamaah). Jadi dakwah jam'iyyah adalah suatu kegiatan usaha dakwah yang pelaksanaannya itu diserahkan kepada beberapa orang. Subyek dakwah Islam adalah semua muslim mukallaf sesuai dengan kemampuan dan kesanggupan masing-masing. Obyek dakwah dapat dibedakan dalam obyek dakwah umum dan obyek dakwah khusus. ${ }^{7}$ Yang dimaksud dengan obyek dakwah umum adalah masyarakat luas yang meliputi umat dakwah dan umat ijabah. Umat dakwah ialah masyarakat luas non Muslim. Sedangkan umat ijabah ialah kaum muslimin.

Tujuan dakwah adalah mempertemukan kembali fitrah manusia dengan agama atau menyadarkan manusia supaya mengakui kebenaran Islam dan mau mengamalkan ajaran Islam sehingga menjadi orang baik. Semakin banyak yang sadar (beriman dan berakhlak al-karimah) masyarakat akan semakin baik. Artinya tujuan dakwah bukan memperbanyak pengikut, tetapi memperbanyak orang yang sadar akan kebenaran Islam. ${ }^{8}$ Apabila dilihat dari sudut pandang yang lain, metode dakwah dapat dilakukan pada berbagai metode yang lazim dilakukan dalam pelaksanaan dakwah. Metodemetode tersebut adalah sebagai berikut:? (1) Metode Ceramah, (2) Metode Tanya Jawab, (3) Metode Diskusi. Media dakwah ialah alat objektif yang menjadi saluran, yang menghubungkan ide dengan umat, suatu elemen yang vital dan merupakan urat nadi dalam totaliteit dakwah. ${ }^{10}$ Bentuk penyampaiannya yang dapat digolongkan menjadi lima golongan besar, yaitu: (1) Lisan, (2) Tulisan, (3) Lukisan, (4) Audio Visual, (5) Akhlaq.

\section{Semangat Aktivitas Keagamaan Jamaah Hadrah}

Jamaah hadrah adalah kumpulan orang yang memainkan alat musik sejenis rebana yang digunakan untuk acara-acara keagamaan seperti acara Maulid Nabi Muhammad SAW. Istilah semangat di dalam KBBI berarti ruh kehidupan yang

${ }^{7}$ Masyhur Amin, Dakwah Islam dan Pesan Moral, 10.

8Susiati, Dasar-dasar Ilmu Dakwah, 52.

'Samsul Munir Amin, Ilmu Dakwah (Jakarta: Amzah, 2009), 101.

${ }^{10}$ Susiati, Dasar-dasar Ilmu Dakwah, 23. 
menjiwai segala makhluk yang mendorong kekuatan badan untuk berkemauan, bersikap, berperilaku, bekerja, bergerak dan lain-lain. Aktivitas adalah kegiatan, kesibukan, keaktifan, kerja atau suatu kegiatan kerja yang dilaksanakan ditiap bagian didalam suatu perusahaan. ${ }^{11}$ Sedangkan pengertian beragama yang dimaksudkan tidaklah hanya berupa ritus-ritus yang sempit, namun juga hendaknya meliputi seluruh nilai kehidupan. Artinya, sejak penghargaan terhadap waktu (disiplin) sampai kepada penghayatan akan hak dan kewajiban sebagai individu atau anggota masyarakat. Sebagai konsekuensinya, semua tindakannya bernilai ibadah selama tidak melanggar batasanbatasan yang telah digariskan agama dan selama tidak bertujuan untuk kerusakan. Dan konsekuensi akhir berupa pahala di akhirat kelak, dimana banyak atau sedikitnya berdasarkan banyak atau sedikitnya seseorang berprestasi. ${ }^{12}$

\section{Analisis Aktivitas Keagamaan Remaja di Desa Tanjungan Kecamatan Driyorejo Kabupaten Gresik}

Sebelum dibentuknya jamaah hadrah Hubbun Nabi, kegiatan keagamaan yang ada di Desa Tanjungan hanya didominasi oleh orang-orang yang sudah tua. Dan kebanyakan dari para remaja lebih suka menghabiskan waktunya dengan hal-hal yang tidak ada manfaatnya diantaranya berkumpul dengan remaja-remaja lain di warung kopi sambil merokok, main kartu remi bahkan kadang-kadang ada yang sambil minum minuman keras. Dengan pergaulan yang seperti itu membuat akhlak remaja Desa Tanjungan jauh dari norma-norma agama sehingga mereka sudah terbiasa dengan mengucapkan kata-kata kotor, tidak mau melaksanakan kewajiban sebagai seorang muslim dan banyak sekali melakukan maksiat yang bahkan melampaui batas. Hal ini sesuai dengan ungkapan dari Imam Samsul Huda (Ketua Jamaah hadrah Hubbun Nabi):

"Kami melihat banyaknya orang-orang terutama remaja yang belum mengenal majelis taklim atau kegiatan keagamaan, mereka terlalu asyik dengan urusan duniawi, banyak berbuat maksiat dan melanggar hal-hal yang dilarang oleh agama sehingga membuat mereka terlalu jauh dari mengingat dan melaksanakan perintah Allah SWT." "13

${ }^{11}$ Tim Penyusun, Kamus Bahasa Indonesia, 32.

${ }^{12}$ Ahmad Qodri Abdillah Azizy, Islam dan Permasalahan Sosial: Mencari Jalan Keluar (Yogyakarta: LkiS, 2000), 80.

${ }^{13}$ Imam, Wawancara, Driyorejo, 10 Juli 2018. 
Karena kurangnya pengetahuan keagamaan remaja tentang pendidikan agama, maka hal itu juga berpengaruh terhadap jalannya kegiatan keagamaan yang ada di Desa Tanjungan. Masjid juga sepi dari kegiatan keagamaan karena kurangnya semangat remaja dalam meramaikan Masjid. Tetapi setelah adanya jamaah hadrah ini, semua berubah menjadi lebih baik. Remaja yang awalnya sering cangkrukan di warung kopi dengan berbagai macam kemaksiatan yang dilakukan, sekarang sudah sangat berkurang. Akhlak remaja juga mulai ada perubahan yang awalnya sering berkata kotor, kini jarang sekali mengeluarkan kata-kata kotor lagi, mereka lebih sopan dan santun kepada orang tua maupun orang lain. Masjid mulai ramai dengan kegitan keagamaan yang dilakukan oleh remaja melalui jamaah hadrah Hubbun Nabi. Hal ini diungkapkan oleh Imam Masjid Bahrul Ulum NU Tanjungan Bapak M. Amin:

"Iya, wong biasanya di masjid itu sepi sekali pas sebelum ada kegiatan keagamaan yang dilakukan remaja masjid ini. Dengan menciptakan suatu kegiatan keagamaan yang baru dan belum ada yaitu dengan menggunakan musik rebana menurut saya hal itu sudah sangat baik sekali. Wong nyatanya juga mereka berhasil mengajak banyak remaja mengikuti kegiatan keagamaan itu."14

\section{Analisis Peran Dakwah Jamaah Hadrah Hubbun Nabi dalam Meningkatkan}

\section{Semangat Aktivitas Keagamaan Remaja Desa Tanjungan Kecamatan Driyorejo}

\section{Kabupaten Gresik}

Aktivitas jamaah hadrah di Desa Tanjungan semakin berkembang, jumlah anggotanya mengalami peningkatan. Walaupun belum semua remaja di Desa Tanjungan mengalami peningkatan semangat dalam melaksanakan aktivitas keagamaan, tapi masyarakat merespon positif dan mendukung keberadaan aktivitas jamaah hadrah tersebut.

Tabel 4.3 Jumlah Anggota Jamaah Hadrah Hubbun Nabi

\begin{tabular}{llccc}
\hline No. & \multicolumn{1}{c}{ Bulan } & Putra & Putri & Jumlah \\
\hline 1. & Juli 2017 & 14 & 6 & 20 \\
\hline 2. & Januari 2018 & 32 & 15 & 47 \\
\hline 3. & Pebruari 2018 & 35 & 18 & 53 \\
\hline 4. & Maret 2018 & 35 & 19 & 54 \\
\hline 5. & April 2018 & 37 & 19 & 56 \\
\hline
\end{tabular}

${ }^{14}$ Muhammad Amin, Wawancara, Driyorejo, 13 Juli 2018. 


\begin{tabular}{lllll}
\hline 6. & Mei 2018 & 42 & 25 & 67 \\
\hline 7. & Juli 2018 & 42 & 25 & 67 \\
\hline
\end{tabular}

Sumber: Dokumentasi jamaah hadrah Hubbun Nabi Desa Tanjungan

Masyarakat di Desa Tanjungan pada umumnya, khususnya para remaja banyak yang senang dan respek terhadap aktivitas jamaah tersebut. Dengan seni hadrah dan keindahan lantunan shalawat yang dibawakan jamaah hadrah Hubbun Nabi ketika pelaksanaan aktivitasnya, sehingga dapat menarik minat remaja Tanjungan untuk mengikuti aktivitas yang ada di dalam aktivitas dakwah jamaah hadrah Hubbun Nabi. Tujuan kegiatan jamaah hadrah Hubbun Nabi di Desa Tanjungan yaitu untuk mengajak para remaja supaya ingat akan kewajiban mereka sebagai umat Islam serta meningkatkan semangat para remaja dalam melaksanakan aktivitas keagamaan sesuai dengan yang diajarkan dalam syari'at Islam. Karena tujuan manusia hidup di dunia tidak lain adalah untuk mengabdi kepada Allah SWT dan Rasulullah SAW, mempertebal keimanan, menjalin kemasyarakatan dengan baik serta adanya kesadaran dalam beribadah.

Dalam melaksanakan dakwahnya, jamaah hadrah Hubbun Nabi tidak bisa berjalan sendiri tanpa adanya seorang da’i. Karena dakwah yang digunakan oleh jamaah hadrah Hubbun Nabi adalah dakwah jam'iyyah yaitu suatu kegiatan usaha dakwah yang pelaksanaannya itu diserahkan kepada beberapa orang. ${ }^{15}$ Dan yang berperan sebagai seorang da’i adalah bidang pendidikan yang diserahkan kepada Ustadz Murtadlo. Ustadz Murtadlo memiliki banyak ilmu pengetahuan, pengalaman, serta kepandaiannya sudah memenuhi syarat sebagai seorang juru dakwah.

Semua anggota berperan dalam pelaksanaan aktivitas dakwah jamaah hadrah Hubbun Nabi. Semuanya saling melengkapi satu sama lain. Ustadz Murtadlo sebagai da'i atau yang mengontrol berjalannya aktivitas dakwah sedangkan jamaah berperan sebagai wadah atau gerakan yang menjadi pendukung utama dalam pelaksanaan dakwah. Sehingga aktivitas dakwah yang dilakukan jamaah hadrah Hubbun Nabi dapat berhasil memenuhi sasaran dan tujuan sesuai dengan yang direncanakan oleh jamaah hadrah Hubbun Nabi. Seperti yang dikatakan Samsul Munir Amin, adanya organisasi yang baik yang mendukung dakwah merupakan suatu keharusan mutlak karena tanpa

${ }^{15}$ Susiati, Dasar-dasar Ilmu Dakwah, 6. 
adanya organisasi, dakwah tidak dapat berjalan dengan baik, bahkan kemungkinan besar akan berhenti. ${ }^{16}$

Aktivitas jamaah hadrah sangat membantu remaja mendapatkan semangatnya lagi dalam melaksanakan aktivitas-aktivitas keagamaan di Desa Tanjungan, dengan kesenian hadrah yang digunakan dalam proses dakwah jamaah hadrah Hubbun Nabi mampu menarik minat para remaja mengikuti aktivitas yang dilaksanakan jamaah hadrah ini. Karena di dalam aktivitas dakwah jamaah hadrah Hubbun nabi ini tidak hanya mengenalkan remaja ilmu tentang hadrah (rebana) dan shalawat saja, tetapi di dalam dakwahnya jamaah hadrah ini banyak ilmu-ilmu lainnya yang diberikan kepada remaja. Berdasarkan hasil wawanacara dari beberapa anggota dan tokoh masyarakat setempat menunjukkan bahwa aktivitas dakwah jamaah hadrah ini dapat meningkatkan semangat remaja Desa Tanjungan. Beberapa remaja yang menjadi anggota jamaah hadrah tersebut menunjukkan sikap yang sesuai dengan sikap-sikap yang menunjukkan adanya semangat dari para remaja tersebut.

a. Adanya kegairahan, hal tersebut bisa dilihat dari: remaja yang selalu hadir setiap ada aktivitas-aktivitas keagamaan yang dilaksanakan jamaah hadrah Hubun nabi. Karena seseorang yang memiliki kegairahan atau semangat berarti juga akan memiliki motivasi dan dorongan untuk selalu melakukan suatu perbuatan yang diinginkan.

b. Adanya kekuatan untuk melawan frustasi, meskipun menabuh rebana itu tidah mudah dilakukan, karena menabuh rebana tidak hanya dengan asal-asalan menabuh saja dan mereka juga baru mengenal alat-alat musik tersebut, tapi mereka selalu belajar dan berusaha untuk bisa dengan cara bersungguh-sungguh berlatih dan aktif berangkat ketika agenda yang dijadwalkan untuk latihan rebana.

c. Adanya kualitas untuk bertahan, banyaknya kendala yang dapat menghambat berjalannya suatu kegiatan tidak membuat pesimis para anggota jamaah melaksanakan aktivitasnya. Meskipun banyak diantara anggota yang berhalangan hadir, anggota yang berangkat hanya sedikit tapi kegiatan tetap dilaksanakan. Karena dalam aspek semangat yang ketiga ini menyatakan bahwa seseorang yang

16Amin, Ilmu Dakwah, 135. 
mempunyai semangat yang tinggi maka tidak akan mudah putus asa.

d. Adanya semangat kelompok, antar remaja satu dengan yang lainnya sama-sama bertahan dengan anggotanya, selalu menjalin hubungan yang baik, mereka selalu bekerja sama, saling membantu dalam mencapai sasaran dan tujuan yang ingin dicapai jamaah hadrah Hubbun Nabi. Jadi semangat kerja di sini menunjukkan adanya kesediaan untuk bekerja sama dengan orang lain agar dapat mencapai tujuan bersama dengan tujuan kita.

Jamaah hadrah selain bermanfaat membantu mengisi waktu luang remaja dengan meningkatkan semangat remaja dalam melaksanakan aktivitas-aktivitas keagamaan, aktivitas jamaah hadrah Hubbun nabi juga berfungsi memakmurkan masjid, karena aktivitas jamaah hadrah ini lebih banyak dilakukan di masjid dari pada di tempat lainnya. Sebelum dibentuknya jamaah hadrah Hubbun nabi, di Desa Tanjungan tidak ada sama sekali aktivitas-aktivitas atau taklim keagamaan untuk remaja. Tapi setelah adanya jamaah hadrah Hubbun nabi tersebut, remaja di Desa Tanjungan sekarang ini banyak yang pergi ke masjid untuk mengikuti aktivitas keagamaan yang dilaksanakan jamaah hadrah Hubun Nabi.

Aktivitas-aktivitas remaja di Desa Tanjungan sangat berfungsi untuk memakmurkan masjid kembali karena dengan adanya aktivitas jamaah ini khususnya setiap PHBI dan hari raya Islam (Idul Firti dan Idul Adha) para remaja berpartisipasi dalam pelaksanaannya. Mulai kegiatan pembagian zakat, mengumandangkan takbir di malam hari raya, hingga mempersiapkan pelaksanaan untuk shalat Id. Selain itu para remaja juga rajin melaksanakan shalat sunnah lainnya seperti mengikuti shalat tarawih di masjid yang dilakukan setiap bulan ramadhan dan sebagainya. Pada acara pengajian PHBI mereka biasanya menjadi pengisi hiburan dengan seni hadrah, serta menjadi pengiring shalawat saat kyai (da'i) mengajak mad'unya melantunkan shalawat. Jadi jamaah hadrah Hubun Nabi memang sangat berperan sekali dalam memakmurkan serta menghidupkan kembali masjid di Desa Tanjungan dengan aktivitas-aktivitas keagamaan remaja yang sudah sekian lama hilang dari budaya para remaja di Desa Tanjungan. 
Para remaja mengakui ada sedikit demi sedikit perubahan pada diri mereka yang awalnya kurang adanya gairah dan keinginan dalam beribadah setelah mengikuti kegiatan tersebut secara berangsur-angsur menjadi lebih bersemangat dalam beribadah dan mengikuti kegiatan-kegiatan agama. Selain itu, remaja juga mendapatkan banyak contoh tentang bagaimana cara berakhlak yang baik terhadap sang pencipta, kepada orang tua dan keluarga, kepada sesama teman, masyarakat dan kepada lingkungan sekitar.

Berdasarkan hasil wawancara dengan beberapa orang tua dari remaja anggota jamaah hadrah Hubbun Nabi, Semenjak anaknya ikut serta dalam kegiatan tersebut, akhlak anaknya secara bertahap menjadi lebih baik, lebih sopan terhadap kedua orang tuanya, bersedia membantu pekerjaan rumah, pekerjaan sawah, serta menunjukkan perilaku yang baik yaitu dengan berpamitan serta mencium tangan orang tua ketika akan berangkat sekolah, tidak hanya itu dalam bertutur kata pun secara bertahap menggunakan bahasa yang lembut sehingga membuat senang hati orang tua. Mereka para orang tua sangat mendukung anaknya mengikuti kegiatan jamaah hadrah Hubbun Nabi, karena dengan mengikuti kegiatan jamaah hadrah Hubbun Nabi sangat membantu orang tua dan lebih meringankan tugas orang tua dalam mendidik dan memberi pendidikan agama pada anaknya. Hal tersebut sesuai dengan ungkapan dari Bapak Hirin (orang tua salah satu anggota jamaah hadrah Hubbun Nabi):

"saya melihat perkembangan anak saya sedikit demi sedikit menjadi lebih baik, dengan orang tua menjadi lebih sopan, mau membantu pekerjaan rumah, membantu saya di sawah, lebih mengerti kondisi orang tua, dan tau apa yang harus dia lakukan."17

Hal yang sama juga diungkapkan oleh Ibu $\mathrm{Hj}$. Suwarti (orang tua salah satu anggota jamaah hadrah Hubbun Nabi):

"saya melihat anak saya sekarang ini ngomongnya lebih santun, kalau mau berangkat ke sekolah itu cium tangan saya dan juga bapaknya dulu. Kalau mau masuk rumah atau mau pergi keluar rumah juga selalu salam dulu. Jadi saya sangat senang melihatnya itu." 18

Hasil dari uraian di atas dapat disimpulkan bahwa dengan adanya dakwah yang dikemas dalam kegiatan-kegiatan yang menyenangkan di dalam jamaah hadrah Hubbun

${ }^{17}$ Hirin, Wawancara, Driyorejo, 14 Juli 2018.

${ }^{18}$ Suwarti, Wawancara, Driyorejo, 15 Juli 2018. 


\section{Suparno}

Nabi sangat membantu meningkatkan gairah dan keinginan dari dalam diri para remaja untuk melaksanakan aktivitas-aktivitas keagamaan serta berupaya membenahi akhlak remaja Desa Tanjungan yang dulunya kurang baik secara berangsur-angsur berubah menjadi lebih baik.

Diketahui bahwa anggota jamaah hadrah Hubbun Nabi adalah para remaja yang masih dalam taraf pendidikan yang rata-rata masih memiliki kondisi emosi yang labil, mudah terpengaruh oleh arus zaman yang kurang baik. Maka jamaah hadrah ini diharapkan bisa menjadi sarana yang tepat untuk melakukan pembinaan akhlak serta meningkatkan semangat aktivitas keagamaan bagi para remaja, sehingga mereka bisa membedakan dan memilih nilai-nilai yang baik untuk diamalkan pada kehidupan seharihari. Metode atau penerapan dakwah yang digunakan oleh jamaah hadrah Hubbun Nabi diantaranya adalah:

a. Melalui seni atau estetika

Aplikasi dakwah melalui seni pada jamaah hadrah Hubbun Nabi adalah dengan alat musik rebana yang dibunyikan untuk mengiringi lantunan-lantunan shalawat dan syair-syair Islami yang berisikan tentang kisah atau nasehat untuk para remaja, sehingga memudahkan untuk diterima. Karena dengan drikikir dan lagu-lagu islami yang diiringi musik digunakan untuk memikat para remaja untuk ikut bergabung dalam jamaah hadrah Hubbun Nabi

b. Ceramah atau Mauidhah Hasanah

Ceramah atau Mauidhah hasanah yang digunakan Ustadz Murtadlo di dalam jamaah hadrah Hubbun Nabi ada 5 ungkapan yaitu: nasehat, tabsyir, tandzir, wasiat dan kisah.

1) Nasehat (anjuran)

Memerintah atau menganjurkan yang disertai dengan motivasi dan ancaman, mengatakan sesuatu yang benar dengan cara melunakkan hati. Nasehat yang diterapkan dalam dakwah jamaah hadrah Hubbun Nabi adalah dengan cara Ustadz menghimbau para remaja dari setiap tingkah laku yang menyimpang dari ajaran Islam. Misalnya saja Ustadz memberi nasehat untuk para remaja agar selalu berada di jalan Allah SWT, menjalankan perintah Allah SWT dan 
menjauhi segala larangan-larangan-Nya, seperti selalu melaksanakan shalat meskipun sesibuk apapun mereka serta melaksanakan rukun Islam yang lainnya sesuai dengan yang diperintahkan agama Islam, menjaga akhlak dan tingkah laku mereka dan menghimbau mereka agar jangan sampai terjerumus pada MIRAS atau perkara-perkara negatif lainnya. Mauidhah basanah (nasehat) tersebut diberikan ketika selesainya kegiatan pembacaan Maulid al-Diba'i dan hadrahan. Dan pada kenyataannya sesuai yang sudah dikatakan oleh beberapa orang tua remaja anggota jamaah hadrah Hubbun Nabi menyebutkan bahwa setelah anaknya mengikuti kegiatan keagamaan tersebut, anaknya sekarang menjadi lebih baik dan lebih sopan terhadap orang yang lebih tua. Hal tersebut merupakan hasil dari pelajaran dan nasehat-nasehat yang diberikan Ustadz Murtadlo dapat diterima dengan baik oleh para remaja yang mengikuti aktivitas-aktivitas keagamaan jamaah hadrah Hubbun Nabi.

Menurut pendapat Rohadi Abdul Fattah dalam bukunya Manajemen Dakwah di Era Global, bahwa pesan dakwah itu harus disampaikan sedemikian rupa agar dapat menyentuh jiwa dan perasaan serta pikiran pendengar, dan tidak disampaikan secara arogan dan berupa instruksi. ${ }^{19}$ Hal tersebut juga sesuai dengan firman Allah dalam surat Thoha ayat 44 yang artinya:

"Maka berbicaralah kamu berdua kepadanya dengan kata-kata yang lemah lembut, Mudah-mudahan ia ingat atau takut."20

Hasil dari uraian di atas, cara yang dilakukan merupakan cara yang efektif untuk membina remaja, karena disampaikan dengan cara yang lemah lembut dan melunakkan hati, dengan demikian pembinaan terhadap para remaja bisa berjalan dengan baik dan tidak menimbulkan suatu ketidak nyamanan pada para remaja yang mendapatkan binaan.

2) Wasiat

Penerapan wasiat di dalam dakwahnya jamaah hadrah Hubbun Nabi adalah termasuk kategori yang utama, yaitu: para Ustadz berpesan kepada para

${ }^{19}$ Rohadi Abdul Fattah dan Tata Taufik, Manajemen Dakwah di Era Global (Sebuab Pendekatan Metodologi) (Jakarta: PT Fauzan Inti Kreasi, 2004), 83.

${ }^{20} \mathrm{Al}$-Quran, 40 (Thaha): 44. 
remaja agar selalu menjaga akidah dan akhlak di manapun mereka berada.

3) Kisah

Ustadz Murtadlo menceritakan kisah pengalaman pribadinya dalam menuntut ilmu, dan kerja keras sehingga bisa menjadi motivasi bagi anggota jamaah hadrah karena orang yang mereka lihat dihadapan mereka telah membawa sebuah keberhasilan dalam hidupnya.

c. Melalui Keteladanan dan Pembiasaan

Aplikasi keteladanan pada jamaah hadrah Hubun Nabi diantaranya adalah pengurus jamaah hadrah memberikan contoh secara istiqomah shalat berjamaah, disiplin waktu, menjaga kerapian, kesopanan dan kebersihan dalam berpenampilan, bertutur kata yang sopan meskipun dengan jamaah yang lebih muda. menghormati orang lain, membantu orang yang membutuhkan pertolongan, mengutamakan kejujuran, membersihkan lingkungan, dan lain-lain.

Aplikasi pola pembiasaan pada kegiatan dakwah jamaah hadrah Hubbun Nabi adalah melaksanakan drikir yang sedikit demi sedikit diterapkan melalui kegiatan hadrah. Membiasakan membaca shalawat pada Nabi agar memambah rasa cinta kepada Rasulullah Muhammad SAW, diajarkan kebiasaan berkomunikasi dengan bahasa yang sopan, menyapa dengan salam, serta menjaga kebersihan dan memelihara lingkungan.

d. Diskusi dan Tanya Jawab

Metode dengan diskusi direalisasikan ketika membahas suatu masalah atau ketika ada suatu permasalahan dalam hal apa saja, dalam hukum-hukum agama maupun permasalahan yang lain, anggota jamaah hadrah Hubbun Nabi selalu berusaha menyelesaikan permasalahan yang terjadi dengan bersama-sama.

e. Metode Silaturrahim

Pada metode silaturrahim ini anggota jamaah hadrah Hubbun Nabi diantaranya adalah melakukan silaturrabim ke tiap-tiap rumah anggota jamaah dengan tujuan untuk mempererat persahabatan dan persaudaraan. 


\section{Analisis Faktor Pendukung dan Penghambat dalam meningkatkan semangat aktivitas keagamaan remaja Desa Tanjungan Kecamatan Driyorejo Kabupaten Gresik}

Berdasarkan hasil observasi dan wawancara dengan anggota jamaah hadrah Hubbun Nabi dan Tokoh-tokoh agama di Desa Tanjungan, faktor yang mendorong dalam meningkatkan semangat aktivitas keagamaan remaja meliputi:

a. Faktor internal

1) Gairah dan kerja sama dari pengurus jamaah hadrah Hubbun Nabi

2) Keikhlasan dan rela berkorban pengurus jamaah hadrah yang tinggi

3) Taraf pendidikan dan pengalaman yang memadai dari pengurus jamaah hadrah Hubbun Nabi

b. Faktor Eksternal

1) Masyarakat sekitar yang religius

Masyarakat desa Tanjungan adalah masyarakat yang religius. Kebanyakan mereka adalah taat beragama dan mayoritas penduduknya pemeluk agama Islam.

2) Lingkungan yang kondusif

Lingkungan masyarakat desa Tanjungan merupakan lingkungan yang kondusif. Sehingga dalam menyampaikan dakwah pada remaja dalam meningkatkan semangat aktivitas keagamaan bisa berjalan dengan tenang dan nyaman.

3) Kebanggaan masyarakat terhadap jamaah hadrah Hubun Nabi dan kepercayaan masyarakat terhadap para pengurus

Sebagian masyarakat mendukung adanya kegiatan dakwah jamaah hadrah Hubbun Nabi. Serta kepercayaan masyarakat terhadap para pengurus manjadi sebuah dukungan dan semangat dalam melaksanakan pembinaan dan memudahkan terlaksananya program-program jamaah dalam meningkatkan semangat keagamaan remaja Desa Tanjungan Driyorejo Gresik.

Adapun faktor-faktor yang menghambat jalannya dakwah jamaah hadrah Hubbun Nabi adalah sebagai berikut:

a. Adanya beberapa orang yang tidak suka dengan aktifitas jamaah hadrah Hubbun Nabi. Sehingga selalu mencari kesalahan dari jamaah hadrah ini dan menebar 
fitnah (berita yang tidak benar) tentang jamaah hadrah Hubbun Nabi.

b. Semakin banyaknya warung kopi free wifi yang dibuka di wilayah sekitar Desa Tanjungan, sehingga mempengaruhi pergaulan anak-anak yang akan menginjak usia remaja.

c. Adanya anggota yang kuliah atau kerja di luar kota, sehingga mereka jarang pulang dan jarang juga mengikuti kegiatan jamah hadrah.

\section{Simpulan}

Setelah melakukan penelitian secara seksama terhadap Peran Dakwah Jamaah Hadrah Hubbun Nabi dalam Meningkatkan Semangat Aktivitas Keagamaan Remaja Tanjungan Kecamatan Driyoreo Kabupaten Gresik, maka penulis dapat mengambil kesimpulan sebagai berikut: (1) Sebelum adanya jamaah hadrah Hubbun Nabi, remaja di Desa Tanjungan masih banyak yang mengabaikan pendidikan, baik pendidikan secara umum maupun agama. Sehingga banyak remaja yang akhlaknya kurang baik dan sering melanggar hal-hal yang dilarang oleh agama. Hal ini juga menyebabkan keadaan Masjid yang sepi dari kegiatan-kegiatan keagamaan. (2) Dakwah jamaah hadrah Hubbun Nabi di Desa Tanjungan sangat berperan dalam meningkatkan semangat remaja Tanjungan dalam melaksanakan aktivitas keagamaan yaitu masjid di Desa Tanjungan kembali hidup dengan segala aktivitas-aktivitas keagamaan dan taklim untuk remaja. Aktivitas-aktivitas yang dilaksanakan jamaah hadrah Hubbun Nabi diantaranya adalah: dzikir, shalawat beserta hadrah, tahlil, pembacaan Maulid al-Diba’̈, pengkajian kitab kuning dan lain-lainnya.

Metode dakwahnya yang dikemas dengan baik, sehingga materi yang disampaikan dapat diterima oleh para remaja melalui kesenian yang begitu dinamis, dalam membaca shalawat yang diiringi dengan tabuhan hadrah (rebana) ternyata sesuai dengan kejiwaan remaja yaitu energik, gembira dan penuh semangat. Faktor yang mendorong dalam meningkatkan semangat aktivitas keagamaan remaja meliputi faktor internal dan faktor eksternal. Sedangkan faktor yang mejadi hambatan dalam melaksanakan dakwah jamaah hadrah Hubbun Nabi di Desa Tanjungan adalah sebagai berikut: (1) Adanya beberapa orang yang tidak suka dengan aktifitas jamaah hadrah Hubbun Nabi. Sehingga selalu mencari kesalahan dari jamaah hadrah ini dan menebar fitnah (berita yang tidak benar) tentang jamaah hadrah Hubbun Nabi. (2) Semakin banyaknya warung kopi free wifi yang 
dibuka di wilayah sekitar Desa Tanjungan, sehingga mempengaruhi pergaulan anak-anak yang akan menginjak usia remaja. Adanya anggota yang kuliah atau kerja di luar kota, sehingga mereka jarang pulang dan jarang juga mengikuti kegiatan jamah hadrah Hubbun Nabi.

\section{E. Daftar Pustaka}

Abdullah, Dzikron. Metodologi Dakwah: Diktat Kuliah. Semarang: Fakultas Dakwah IAIN Walisongo, 1988.

Adawy, Musthafa. Fikih Akhlak. Jakarta: Qisthi Press. 2005.

Agustiani, Hendiati. Psikologi Perkembangan: pendekatan ekologi kaitannya dengan konsep diri dan penyesuaian diri pada remaja. Bandung: PT Refika Aditama, 2009.

Alami, Helmi Nur. "Hadhoro-Yuhdhiru-Hadhron-Hadhrotan." Accessed 2018. http://www.akumassa.org/hadhoro-yuhdhiru-hadhron-hadhrotan/2010/29/01

Al-Quran dan Terjemah.

Alwy, Susiati. Dasar-dasar Ilmu Dakwah. Surabaya: Alpha, 2010.

Amin, M. Masyhur. Dakwah Islam dan Pesan Moral. Jakarta: Al Amin Press, 1997.

Amin, Samsul Munir. Ilmu Dakwah. Jakarta: Amzah, 2009.

Arikunto, Suharsimi. Prosedur Penelitian Suatu Pendekatan Praktis. Jakarta: Rineka Cipta, 2002.

Aziz, Moh. Ali. Imu Dakwah, Cetakan Ke 2. Jakarta: Kencana, 2009.

Azizy, Ahmad Qodri A. Islam dan Permasalahan Sosial: Mencari Jalan Keluar. Yogyakarta: LkiS. 2000.

Darodjah, Zakiyah. Pembinaan Remaja. Jakarta: Bulan bintang, 1976.

Fahrunnisa."Minat Jamaah Majelis Taklim Nurul Musthofa Terhadap Kesenian Islam Hadrah.” Skripsi. Universitas Islam Negeri Syarif Hidayatullah Jakarta, 2011.

Fajrikah, Nayik."Peran Dakwah Jama'ah Hadrah Al-Fana dalam Meningkatkan Semangat Aktivitas Keagamaan Remaja". Skripsi. UIN Walisongo Semarang, 2015.

Fattah, Rohadi Abdul dan Tata Taufik. Manajemen Dakwah di Era Global (Sebuah Pendekatan Metodologi). Jakarta: PT Fauzan Inti Kreasi, 2004.

Gunarsa, Singgih D. Psikologi Remaja. Jakarta: BPK Gunung Mulia, 1978.

Hasjmi, Aly. Dakwah Menurut Al-Qur'an. Jakarta: Bulan Bintang, 1974.

Isma'il Ibnu Katsir. Tafsir Ibnu Katsir, ditahqiq oleh Abdullah bin Muhammad bin Abdurrahman bin Ishaq Al-Sheikh, Jilid V. Bogor: Pustaka Imam Asy-Syafi'I, 2004.

Masluchi, Iqbal. "Apa Itu Hadrah.” Accessed 2018. http:/ /tafsirkelas12.blogspot.in/2016/04/apa-itu-hadrah.html?m=1 


\section{Suparno}

Moleong, Lexy J. Metodologi Penelitian Kualitatif. Bandung: Alfabeta, 1993.

Munawwir, Achmad Warson. Kamus Arab Indonesia al-Munawnir. Surabaya: Pustaka Progresif, 1997.

Musthafa, Ahmad. Tafsir al-Maraghi, Jilid I. Mesir: Darul Fikri, 1365 H.

Rasjid, Sulaiman. Fiqh Islam. Bandung: Sinar Baru Algensindo, 2011.

Saputra, Wahidin. Pengantar Ilmu Dakwah. Jakarta: Rajawali Pers, 2011.

Sarwono, Sarlito Wirawan. Psikologi Remaja. Jakarta: PT Remaja Grafindo Persada, 2004.

Shaleh, Rasyad A. Management Dakwah Islam. Jakarta: Bulan Bintang, 1977.

Shihab, M. Quraisy. Membumikan ALqur'an, Fungsi dan Peran Wabyu dalam Kehidupan Masyarakat. Bandung: PT Mizan Pustaka, 2001.

Soekanto, Soerjono. Sosiologi Suatu Pengantar, Cet. 23. Jakarta: PT Raja Grafindo Persada, 1996.

Sugiyono. Metode Penelitian kuantitatif, kualitatif dan Kombinasi (Mixed Methods). Bandung: Alfabeta, 2013.

Suharso dan Ana Retnoningsih. Kamus Bahasa Indonesia Lengkap, Cet. 3. Semarang: CV. Widya Karya, 2009.

Syamsuddin. Pengantar Sosiologi Dakwah. Jakarta: Kencana, 2016.

Tim Penyusun Kamus Pusat Bahasa. Kamus Bahasa Indonesia. Jakarta: Pusat Bahasa, 2008.

Wikipedia. “Jama'ah.” Accessed 2018. http://id.m.wikipedia.org/wiki/Jamaah

Ya'kub, Ali Musthafa. Sejarah Dan Metode Dakwah Nabi. Jakarta: Pustaka Firdaus, 1997. 